Dieses Dokument ist eine Zweitveröffentlichung (Verlagsversion) /

This is a self-archiving document (published version)

„Dieser Beitrag ist mit Zustimmung des Rechteinhabers aufgrund einer (DFG-geförderten) Allianzbzw. Nationallizenz frei zugänglich."

This publication is openly accessible with the permission of the copyright owner. The permission is granted within a nationwide license, supported by the German Research Foundation (abbr. in German DFG).

https://www.nationallizenzen.de
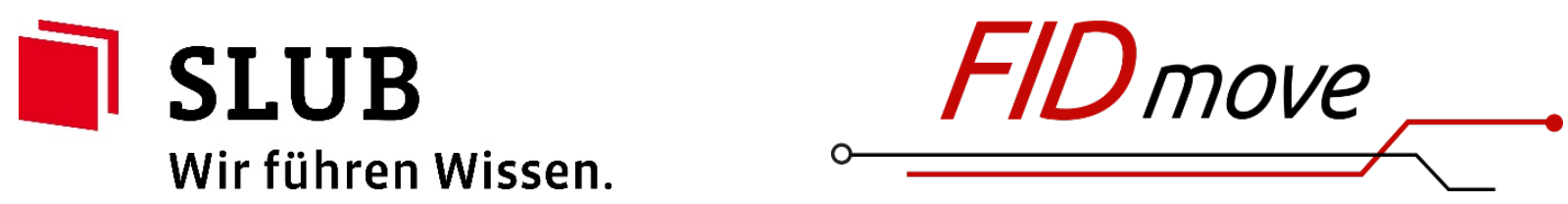


\title{
Criteria for solid recovered fuels as a substitute for fossil fuels - a review
}

Waste Management \& Research 3014) 354-369

(C) The Author(s) 2012

Reprints and permission:

sagepub.co.uk/journalsPermissions.nav DOI: 10.1177/0734242X12441237

wmr.sagepub.com

(S)AGE

\author{
Michael Beckmann, Martin Pohl, Daniel Bernhardt \\ and Kathrin Gebauer
}

\begin{abstract}
The waste treatment, particularly the thermal treatment of waste has changed fundamentally in the last 20 years, i.e. from facilities solely dedicated to the thermal treatment of waste to facilities, which in addition to that ensure the safe plant operation and fulfill very ambitious criteria regarding emission reduction, resource recovery and energy efficiency as well. Therefore this contributes to the economic use of raw materials and due to the energy recovered from waste also to the energy provision. The development described had the consequence that waste and solid recovered fuels (SRF) has to be evaluated based on fuel criteria as well. Fossil fuels - coal, crude oil, natural gas etc. have been extensively investigated due to their application in plants for energy conversion and also due to their use in the primary industry. Thereby depending on the respective processes, criteria on fuel technical properties can be derived. The methods for engineering analysis of regular fuels (fossil fuels) can be transferred only partially to SRF. For this reason methods are being developed or adapted to current analytical methods for the characterization of SRF. In this paper the possibilities of the energetic utilization of SRF and the characterization of SRF before and during the energetic utilization will be discussed.
\end{abstract}

\section{Keywords}

Solid recovered fuel, fuel properties, calorific value formula, ash melting behaviour, batch-reactor, fouling layer probe

\section{Introduction}

Recovered fuels are substitutes for solid, liquid and gaseous fossil fuels, e.g. using scrap tires and oil residues in cement pyroprocessing, or using blast furnace gas in an industrial boiler, etc. This paper will only deal with solid recovered fuels (SRF) from highcaloric fractions of municipal solid waste, bulky waste, industrial waste, scraps from waste sorting, etc. These wastes and waste fractions accumulate as mono-fractions or as mixed fractions, which can be used directly as SRF or indirectly, after further processing.

Solid recovered fuel substitutes for regular (fossil) fuels directly, for example, in coal-fired power plants (Thiel, 2007) or in primary industry (Scur, 1999), and indirectly, when it is used in power plants that are built exclusively for SRF (Weber et al., 2007). The final energy provided in these plants substitutes for the final energy generated by fossil fuel-fired power plants. The portion of the national energy supply provided due to the energy recovered from waste widely varies from country to country as shown in Sommer and Ragossnig (2011).

Solid recovered fuels produced from waste fractions are difficult fuels that have special processing requirements. From a process engineering perspective, there are extensive opportunities for process design and control. Difficulties in substituting fossil fuels, and also in planning new facilities and in equipment optimization, often arise due to absent or insufficient data on the properties of these fuels.
Fossil fuels - coal, crude oil, natural gas, etc. have been extensively investigated due to their longstanding application in plants for energy conversion, as well as in the primary industry. Thereby, criteria for the properties needed from fuels for each process can be derived. In assessing a fuel from a technical perspective (Figure 1), particularly the properties listed here:

- chemical,

- mechanical,

- calorific and

- reaction technical properties

must be considered (e.g. Boie, 1957; Gumz, 1962; Weber, 2005; Zelkowski, 2004). These are discussed for SRF, for example, in Beckmann et al. (2003), Beckmann and Scholz (2006), Eckardt (2005) and Thiel (2007).

Technische Universität Dresden, Faculty of Mechanical Engineering, Institute of Power Engineering, Dresden, Germany

\section{Corresponding author:}

Michael Beckmann, Technische Universität Dresden, Faculty of Mechanical Engineering, Institute of Power Engineering, Chair for Combustion, Heat and Mass Transfer, Walther-Pauer-Bau, George Bähr Str. 3b, 01069 Dresden, Germany Email: Michael.Beckmannatu-dresden.de 


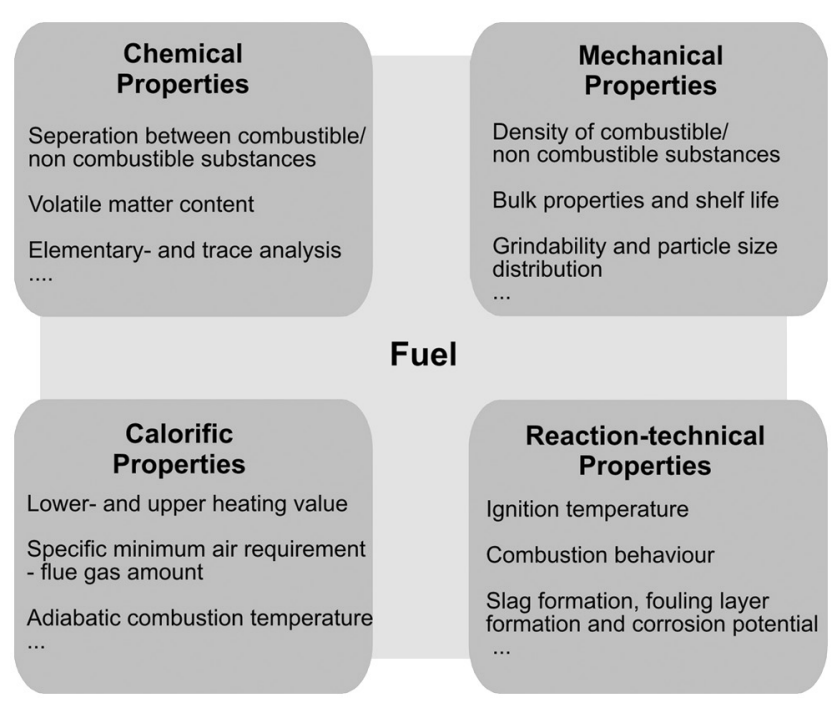

Figure 1. Fuel properties.

In assessing the criteria for the use of SRF, it is important to ensure that the specific application, as well as the relevant technical processes and apparatuses, have also been considered.

The methods used in the engineering analysis of regular fuels (e.g. coal) can only be partially transferred to SRF. For this reason, new methods are being developed, or current analytical methods for the characterization of fossil fuels are being adapted to the characterization of SRF.

At the European level, the working group CEN/TC343 Solid Recovered Fuels should be mentioned, especially for their specifications of the issues of terminology, classification, specification, description of sampling methods, chemical, physical and mechanical tests, etc. Other work has gone beyond the methods mentioned considering the reaction technical properties and the interactions between defined fuel technical parameters, the behaviour of fuels in different furnaces (e.g. Weber, 2005) and the influence of SRF co-combustion (e.g. AIF, 2009; Kupka et al., 2008).

By comparing the properties of SRF with those of regular fuels, usage criteria can be derived, and conclusions about the amount of processing required in each case can be drawn. In this context for example, the energy used for the SRF processing treatment must be considered. This means that the limits for mass, material and energy balances are to be determined and contrasted with processes without pre-treatment of waste (direct use in a municipal solid waste incineration plant) (Scholz and Harnaut, 2002). In particular, statements about energy value (calorific properties, energy exchange ratio) can be derived for SRF use in primary industry (Beckmann and Scholz, 1999).

In the assessment process, SRF use cannot be considered in terms of substitution alone. Rather, the entire process must be considered - the production of fuel, its specific use in the application, and the treatment of the remaining waste. This approach is the only way to ensure that the final energy generated by the SRF is a true substitute for the final energy generated by fossil-fuel power plants.

In addition to the criteria that should be established before the use of SRF, monitoring fuel quality during operation is also

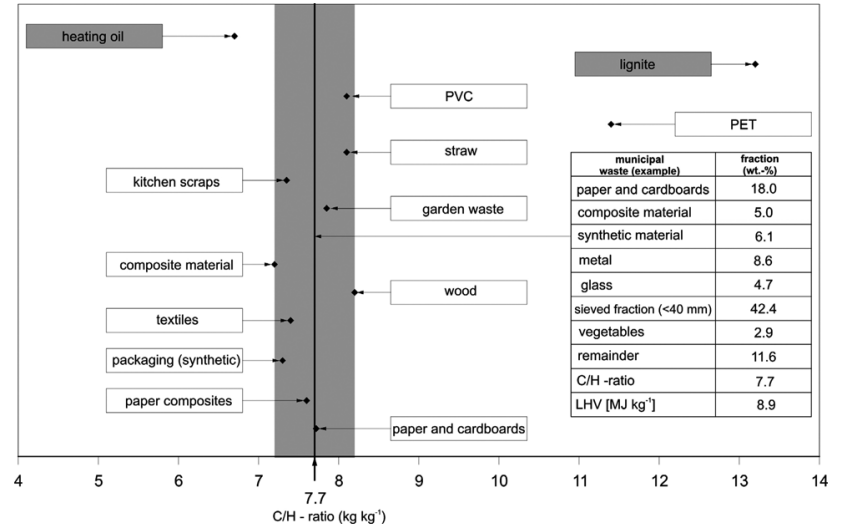

Figure 2. $\mathrm{C} / \mathrm{H}$ ratio of different waste fractions.

necessary, because SRF quality, and therefore fuel properties, can vary widely.

Online measurements are especially suited for this task, since they reflect the actual situation in the plant, whether permanently or only temporarily. Examples of these measurements are an online balancing program that determines the elemental composition and lower heating value (LHV) of a fuel based on operational data (Horeni, 2007), as well as various probe measurements that determine, for example, the heat flux density (Grahl and Beckmann, 2010), the composition of particles in the exhaust gas (Pohl et al., 2010) or the ash-to-salt ratio at the end of the boiler (Spiegel, 2006).

\section{Use of recovered fuel}

\section{From waste to recovered fuel}

The material composition of waste varies based on the region and the season. First, local municipal waste can be subdivided into material groups (i.e. fractions), such as metal, glass, plastics, composite materials, fine waste, paper/cardboard, plant matter, etc. (Figure 2).

From a fuel engineering perspective, it is appropriate to follow the description of fossil fuels with subdivisions into these components: water, inert material and organic fuel substances. In waste, organic fuel substances are further differentiated into synthetic materials (plastic) and other organic components. In a similar way, as fossil fuels are differentiated by ash and mineral content, waste material can also be differentiated according to ash and inert material content (Pohl et al., 2008).

Processing waste into SRF should include pollutant reduction, for example, ridding the waste of metals, non-metals, contaminants (e.g. mineral products and PVC-containing plastic fractions). At the same time, the SRF should be depleted of elements such as chlorine, cadmium, zinc, lead, etc. As part of the RAL GZ 724 quality seal, limits have been defined on pollutant concentrations of selected elements (BGS, 2008). Skutan and Brunner (2006), however, found that the concentrations of the metals $\mathrm{Ca}, \mathrm{Cr}, \mathrm{Cu}$, $\mathrm{Ni}, \mathrm{Pb}, \mathrm{Zn}, \mathrm{Hg}$ in different recovered fuels investigated were only in some cases, and then only for some elements, considerably better than the concentrations of these elements in the waste. 


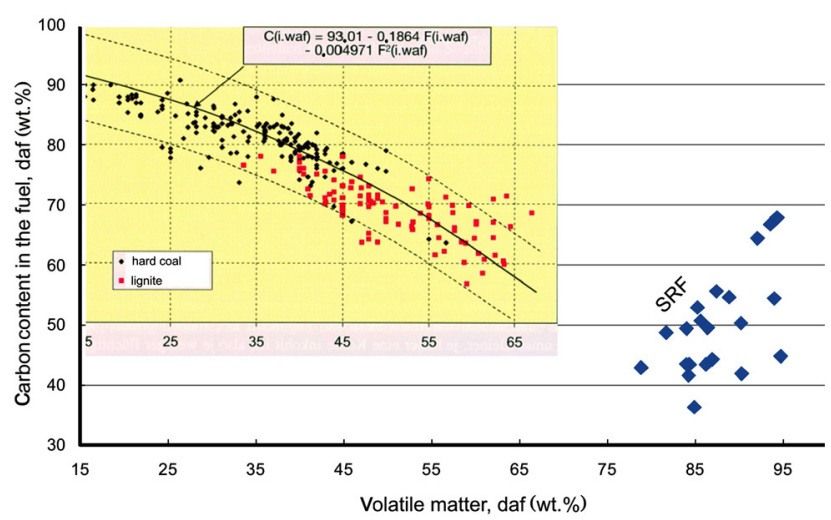

Figure 3. Comparison between volatile matter and C-content of the fuel of different coals and different SRF.

Sampling, sample preparation and analysis of pollutant levels are difficult problems for SRF. Because of the heterogeneity of these fuels, it is difficult to take representative samples. At this time, widely varying methods of sampling and sample preparation are being explored and discussed (e.g. BGS, 2008; SchadeDannewitz et al., 2009; Skutan and Brunner, 2006).

In the preparation of waste into solid recovered fuels (SRF), the water and inert material components in particular are separated, thereby enriching the organic fuel substance and simultaneously increasing the LHV.

The contents of the volatile matter are not influenced by the separation of water at first, and through the reduction of inert material, a relative enrichment of the organic substance results. Figure 2 shows that, for waste and for the various waste fractions, the $\mathrm{C} / \mathrm{H}$ ratio ranges between 7 and 8 . A relative enrichment of plastic (except for PET) in comparison with biogenic material groups, such as kitchen waste, paper/cardboard shows no significant change in the $\mathrm{C} / \mathrm{H}$ ratio. However, an increase in the $\mathrm{C} / \mathrm{O}$ ratio with rising $\mathrm{C}$ content must be noticed.

In contrast to fossil fuels, an increase in the LHV is not based on a change in the fuel structure (increased carbonization), but on the relative enrichment of the organic fuel substance and particularly the enrichment of plastics. The content of the volatile matter in SRF does not, as in fossil fuels, decrease with an increase in the $\mathrm{C}$ content (equivalent to increasing calorific value), but remains approximately constant, or even slightly increases (Figure 3). This means that the behaviour of these fuels during combustion will be different in comparison with fossil fuels.

\section{Possible applications}

Solid recovered fuels are supposed to replace fossil fuels. This means that its application process, in terms of production capacity, product quality, lifetimes of the technical facilities (period between maintenance outages), energy consumption and the emission of pollutants should change as little as possible.
Application in power plants. For existing coal combustiondesigned boiler systems, the behaviour of the fuel with respect to ignition, flame image, slagging, fouling, carbon content in the ash, burnout, and emissions $\left(\mathrm{NO}_{\mathrm{x}}, \mathrm{SO}_{\mathrm{x}}, \mathrm{CO}\right.$, dust, etc.) are mostly known.

For co-combustion of SRF in coal-fired power plants, the operator must take particular aspects into account.

The often heterogeneous composition of SRF, which always brings with it a change in combustion characteristics, must correspond to the demands of the boiler, which has been designed to burn coal. The content and properties of the volatile components and the ash composition of the fuel, for example, significantly impact the combustion characteristics.

Experience has shown (e.g. Hannes and Wachenhausen, 1999; Sander, 2000; Tamura et al., 2001) that the combustion characteristics of a fuel blend of fossil fuels and SRF cannot be judged by the mass fractions in the mixture, since the release of volatile components takes place at different times and leads to interactions (e.g. Haas et al., 2001; Scheurer et al., 2000).

Another problem is based on the interaction of different ash compositions in the fuels. Because of different melting points (e.g. $\mathrm{NaCl}, \mathrm{KCl}$ ), the components that become gaseous first will be released, leading to the formation of substantial deposits on the boiler walls in the incinerator.

Application in the cement industry. A consequence of the use of SRF in cement industry kilns has been a change in flame characteristics (ignition, flame stability and flame shape) (Scur, 1999).

Due to different proportions of volatile matter in the different fuels, local changes in heat transfer conditions are to be expected, especially in the case that large quantities of SRF are used (e.g. EdDE, 2003; Hoenig, 1998; Kehl et al., 1998; Weber et al., 2002). As a consequence, the temperature profile is altered, which can have an impact on product quality. The safe use of SRF in cement kilns, therefore, requires that appropriate criteria be set not only for pollutants but also for the reaction technical properties of the fuel.

Application in SRF mono power plants. In most cases, the use of SRF in power plants built especially for these fuels will not lead to deviations from conventional waste incinerators (Gleis and Raesfeld, 2011), mostly stoker-fired furnaces, with respect to the technological process and the parts/equipment used. Compared to a conventional waste incinerator, SRF power plants differ only in terms of the fuel used. In some cases also fluidized bed incinerators are used.

\section{Process requirements}

Using SRF in power plants as a substitute for fossil fuels should not compromise the availability of the plants. Furthermore, no significant change in pollutant release should result, and the efficiency of the system should not deteriorate. These requirements also apply for use in mono power plants, namely high 


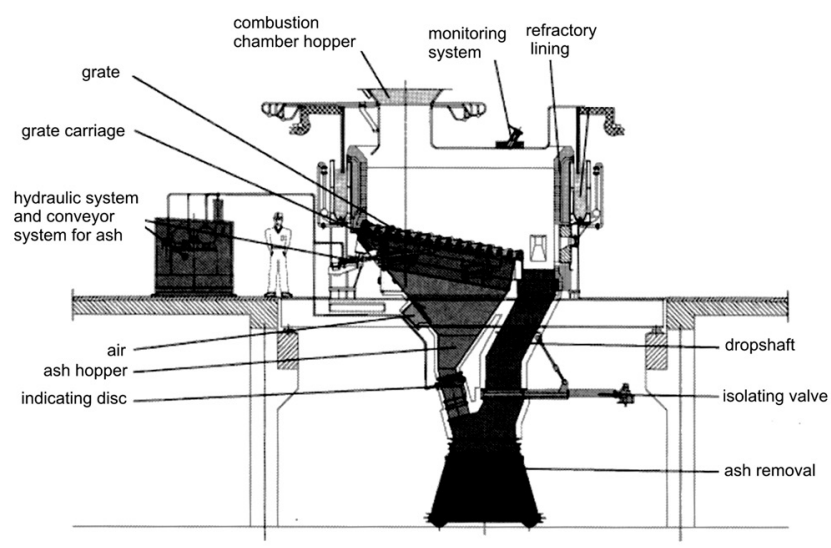

Figure 4. Sketch of a burnout grate (Reproduced from Thiel, 2007 with permission from Hitachi Power Europe GmbH).

availability, low emissions and optimization in terms of operating efficiency in comparison to classic waste incinerators.

When SRF is used in the primary industries, for example, in cement production, the product is, of course, in focus, in this case the cement clinker, the quality of which should not be adversely affected by the fuel mixture.

The realization of these requirements is mainly determined by the fuel and its properties, but also through process control, as well as by the apparatus used in each power plant. The process control, namely the process itself and its technical process engineering control, is to be considered in the mixing of reaction gases and fuel, in the separation of reaction and heat transfer, the temperature levels and gradients, and conditions for emissions control. It is especially important to consider the reaction technical properties, of course, dependent on the chemical, calorific and mechanical properties of the fuels.

When using SRF, the relevant or available apparatuses (combustion chamber, rotary kiln, grate, fluidized bed, etc.) are to be examined with regard to their suitability for the particular fuel.

The suitability of combustion chamber systems (e.g. drybottom boiler, slag-tap boiler), as found in dust-firing coal combustion power plants, is limited for SRF, because, for example, the rate of combustion is lower for SRF compared to coal dust due, for example, to larger SRF grain size. Thus, complete combustion cannot be guaranteed in every case.

For this reason, very high fuel treatment demands are set for the use of SRF in hard coal-fired power plants. In lignite-fired power plants, which are equipped with a burnout grate (Figure 4) or have an ash recirculation apparatus, the incomplete burnout problem is solved by appropriate engineering of the process or the apparatus. Thus, such plants are well-suited for alternative fuels (Thiel, 2011).

Comparatively fewer problems exist with the firing systems for alternative fuels used in grate and fluidized bed systems, as the residence time there is quite long in comparison with pulverized coal firing.

Furthermore, the fuel mixes thoroughly with the reaction gas, for example, through mixing on the grate and through the adjustable air flow over the grate length or, for fluidized bed

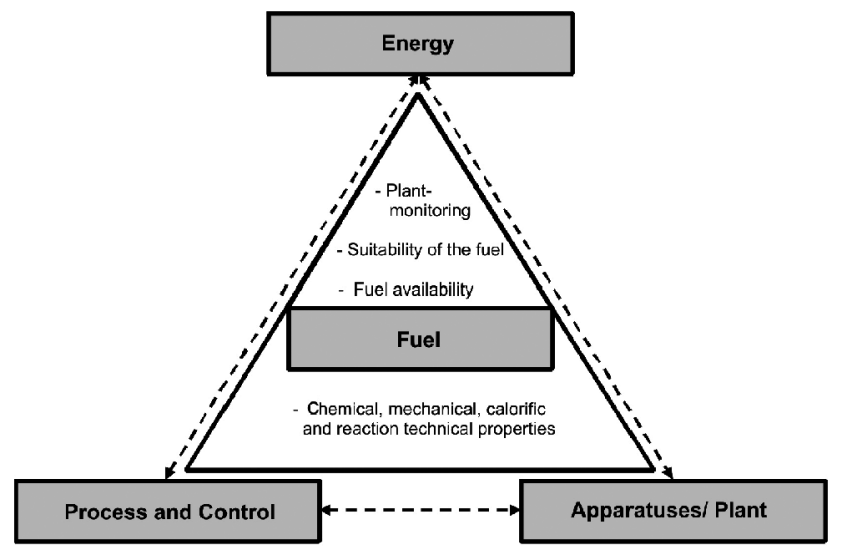

Figure 5. Dependencies in the use of a fuel.

systems, through fluidization and intense contact with the bed material.

The use of SRF in rotary kilns is state of the art for cement production, due to the robust and simple technology of the apparatus. SRF can be used in the kiln inlet or in the calcinatory. The fuel feed into the rotary kiln is often realized with a special burner or with injector lances. Aside from use as a fuel, the SRF ash can be utilized as a raw material in a cement rotary kiln.

When using SRF, different mechanical properties (e.g. bulk density, energy density, grindability and grain size) require the consideration of storage options, fuel feeding, as well as emission control components in the plants and ash removal systems (due to chemical properties e.g. ash content, heavy metals, sulfur, chlorine content) in addition to considerations regarding the combustion system itself.

In Figure 5 the complex relationships are summarized, focusing on the fuel and its properties. Criteria for fuel suitability are to be determined only with regard to the individual apparatuses. The requirements mentioned above (residence time, pollutants and efficiency) depend on the particular process and its controls.

The question of long-term, consistent fuel availability, namely the qualities and potential of the fuels, must also be considered, which is only possible through regular sampling of the plant input materials, or by an online monitoring system which monitors fuel quality during the process.

In addition, the fuel properties and the methods for investigating them will be presented and discussed, along with the possibility for monitoring plants to achieve continuous monitoring of fuel quality.

\section{Fuel characterization to determine criteria for the use of SRF}

\section{Fuel properties and test methods}

The chemical (e.g. element analysis, trace analysis, ash analysis), mechanical (e.g. bulk density, particle size/particle size distribution) and calorific properties (e.g. LHV, adiabatic combustion temperature, minimum air consumption) of various SRF, biomass fuels and fossil fuels are shown in publications such as Boie 


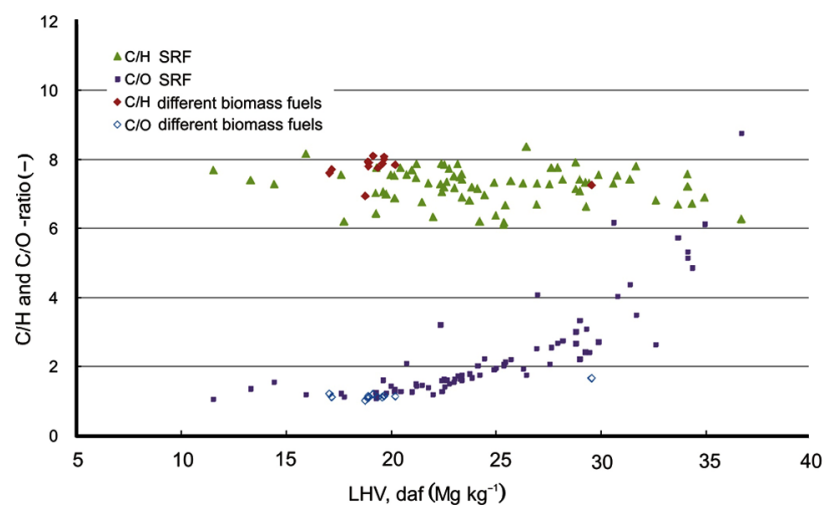

Figure 6. $\mathrm{C} / \mathrm{H}$ and $\mathrm{C} / \mathrm{O}$ - ratio of different biomass fuels and of SRF.

(1957), Gumz (1962), Zelkowski (2004), Tamura et al. (2001) and Pohl et al. (2010).

Standardized testing methods for biomass fuels and SRF are based on those for standard fuels (coal, coke, lignite, peat, charcoal, briquettes, etc.); however, they may differ slightly.

For example, the ash content of SRF (DIN EN 15403 (DIN, 2011)) and solid biomass fuels (DIN EN 14775 (DIN, 2010)) is measured at a temperature of $550 \pm 10{ }^{\circ} \mathrm{C}$, whereas for standard fuels, ash content is determined at a temperature of $815 \pm 10^{\circ} \mathrm{C}$, according to DIN 51719 (DIN, 1997). The standard used is to be indicated with the results of every fuel investigation.

Correlations between LHV and elemental composition. Based on conventional investigations of the chemical, mechanical and calorific properties of fuels, it is interesting to look at the LHV in context of the elemental composition. It can be inferred from initial considerations of the $\mathrm{C} / \mathrm{H}$ ratios of different waste fractions that, for SRF, the $\mathrm{C} / \mathrm{H}$ ratio remained approximately constant as the LHV increased, while the $\mathrm{C} / \mathrm{O}$ ratio increased. In this context Figure 6 shows an analysis of various waste fractions, waste mixtures and SRF.

Based on these relationships, it is possible to determine a calorific value formula especially designed for SRF:

$$
\begin{aligned}
L H V & =45.09 c-4.99 o \\
& -2.44 w\left[L H V \text { in } \mathrm{MJ} \mathrm{kg}^{-1} ; c, o, w \text { in } \mathrm{kg} \mathrm{kg}^{-1}\right]
\end{aligned}
$$

as shown in (Pohl et al., 2008). The deviations of the values calculated with this formula from the experimental values are shown in Figure 7.

\section{Ignition and combustion behaviour}

To determine reaction technical properties, for example, for the determination of kinetic data, the conditions of the process must be considered. Widely varied experimental facilities, such as a drop-tube reactor for the determination of kinetic data of fast processes (process conditions similar to pulverized

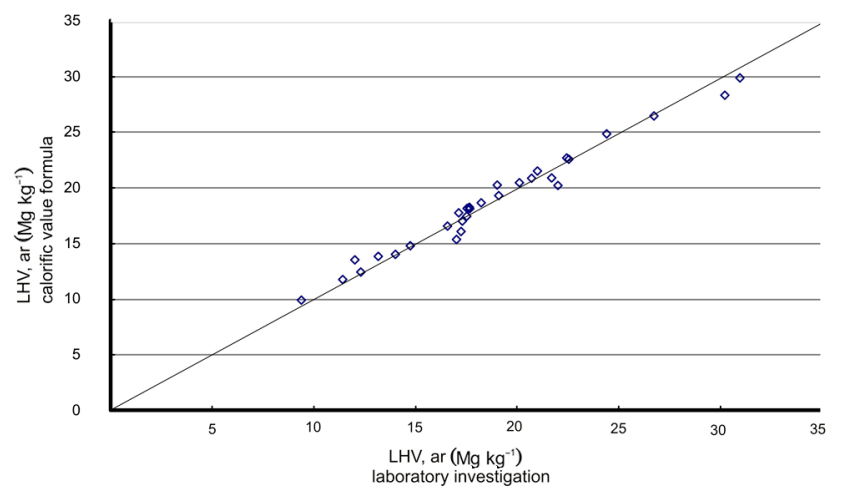

Figure 7. Comparison of experimentally evaluated LHV to the one evaluated through the calorific value formula.

coal combustion); and a TGA (thermogravimetric analysis) to determine kinetic data for slow processes (process conditions similar to grate firing systems) were available. In Figure 8 these facilities are shown. The experimental procedure and the resulting kinetic data for the reaction are described and discussed for example in (Unz et al., 2010).

In both systems, only very small sample masses are used to study combustion behaviour. For drop tube investigations, the fuels are prepared (ground) to a specific particle size. The grain size is of the order of that of coal in pulverized coal firing. Grinding the fuel is also necessary in conventional TGA, since only small amounts of samples can be examined. Ignition and combustion behaviour, and thus the release of particulate and gaseous components, are influenced by conditions for the heatand mass transfer.

During SRF preparation for the use in power plants, they are ground to a maximum grain size of a few centimetres (typical grain sizes of 30-100 mm (Thiel, 2011)). Further grinding in the power plant mill takes place only conditionally; therefore, this is also the application grain size.

In determining the TGA kinetic data, as well as for a drop tube, the SRF must be prepared (ground) to a grain size of, typically, $<0.25 \mathrm{~mm}$, which means that this fuel cannot be studied in its application grain particle size $(30-100 \mathrm{~mm})$ - this must be noted and is especially important for transfer of the kinetic data to real applications.

In addition to the drop tube reactor and the TGA, other experimental systems are available for determining the reaction technical properties, such as an ignition furnace (TUD, 2011; Zelkowski, 2004) that determines the ignition rate of pulverized fuels.

In Figure 9 the ignition behaviour of various fuels is shown. The diagram depicts investigations at different ignition furnace temperatures to determine the ignition point related to a specific temperature and residence time. When coal has a high percentage of volatile compounds, the ignition point is usually at a low temperature, which means fast ignition (Zelkowski, 2004). The comparison of lignite and hardcoal (Figure 9) supports this hypothesis. The ignition behaviour of the investigated biomass fuels ranges between the two curves of lignite and hardcoal. 


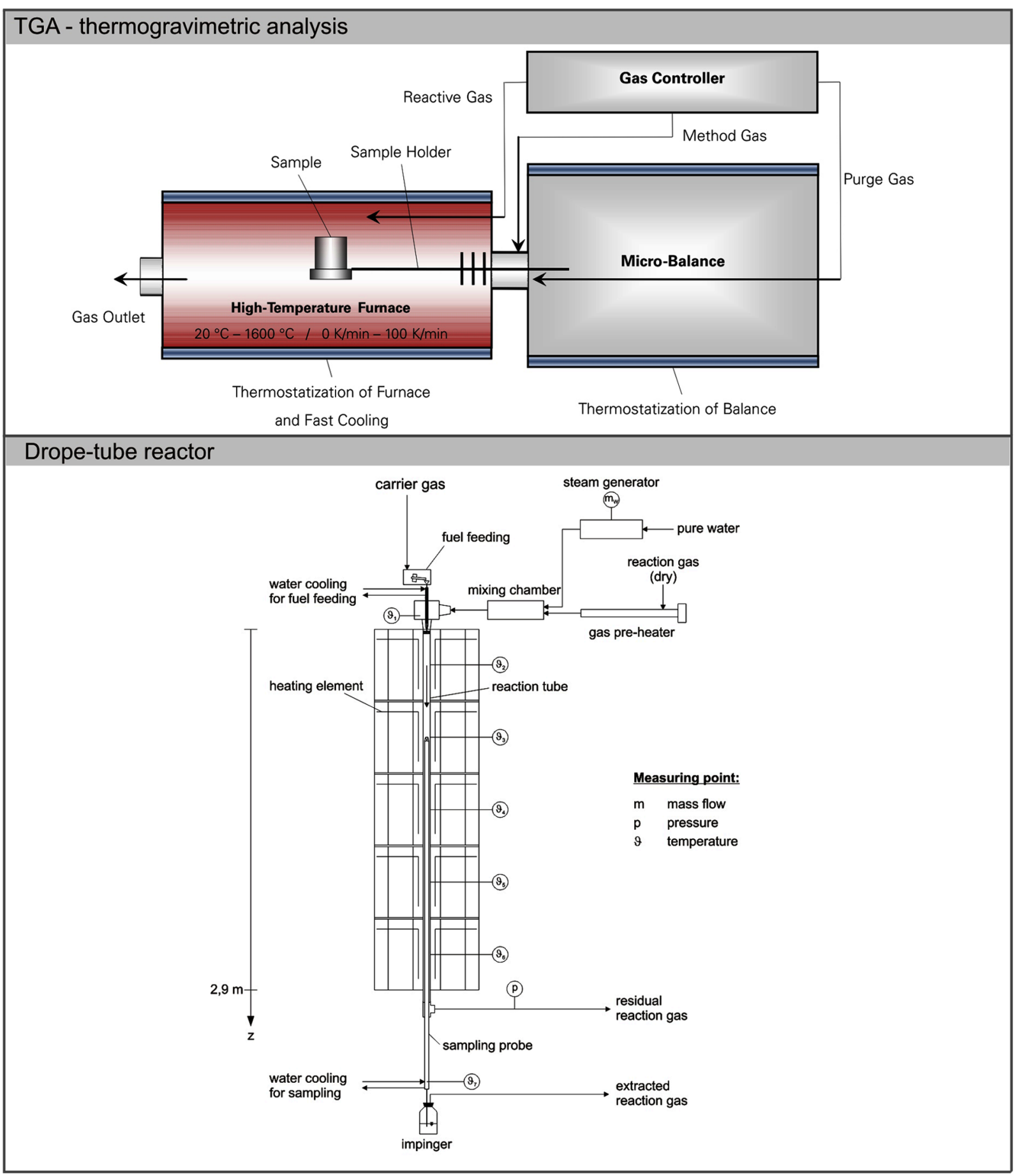

Figure 8. Sketch of the thermogravimetric analysis and the drop tube reactor.

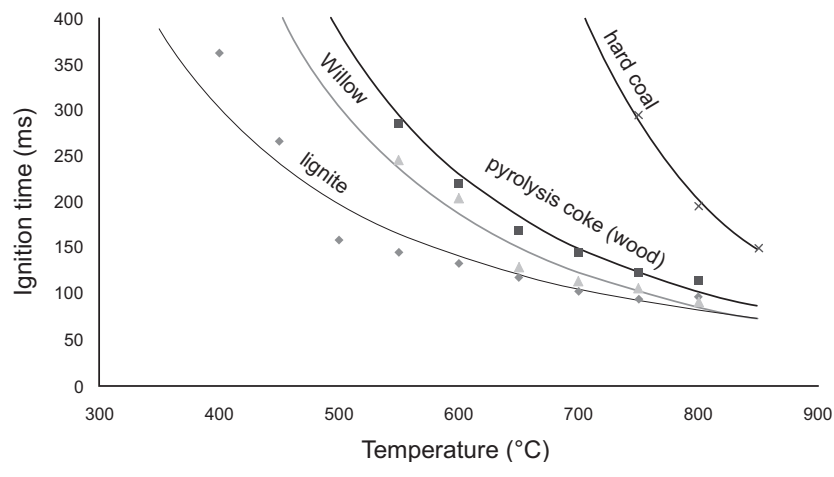

Figure 9. Ignition time of various fuels.
Experimental systems in which the reaction technical properties of larger amounts of samples with each application grain size can be studied are, for example, the Batch-Reactor (TUD, 2011) and the technical TGA(IEVB, 2011). The sketch of the above-described ignition furnace and the Batch-Reactor is shown in Figure 10.

Experiments with regard to the characterization of the combustion process for anthracite coal and the temperature characteristics in the fuel bed were initially carried out in Batch-Reactors in the early 1930s (Tanner, 1933; Werkmeister, 1932). During that period, the Batch-Reactor was used to optimize the construction and operation of grate-fired systems. Particularly in 


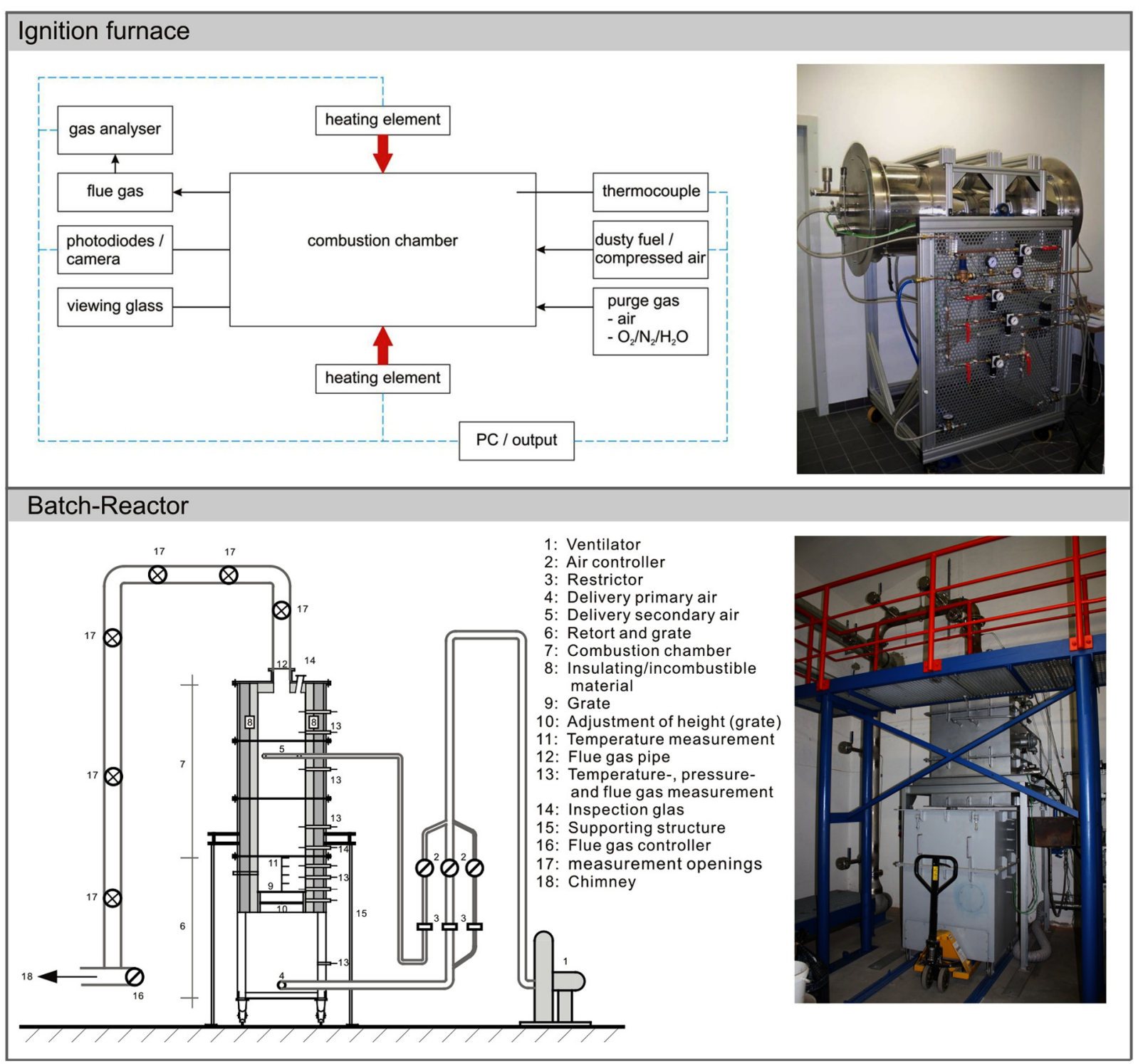

Figure 10. Sketch of the ignition furnace and the batch-reactor.

Werkmeister (1932), the following question was asked: 'Do we know our fuels well enough to establish the best possible conditions during combustion, and how do the fuels behave during combustion under imposed operational conditions?'

From these questions, various methods were developed (Zelkowski, 2004) for conventional fuels that allowed them to be classified according to their application.

The possibility of characterizing SRF was investigated, among others, with the aid of a Batch-Reactor in a research study project (AIF, 2009). In the project, different parameters, including reaction front velocity (e.g. Bleckwehl et al., 2002, 2004; Porteiro et al., 2010), were compared with one another in investigations of different fuels under nearly the same experimental conditions in three Batch-Reactors of different constructions. The results of the investigations indicated only small variations. Thus the suitability of the Batch-Reactor as a method for characterizing fuel was verified.

As an example, Figure 11 presents the reaction front velocity of coal under variations in the amount of primary air, and of

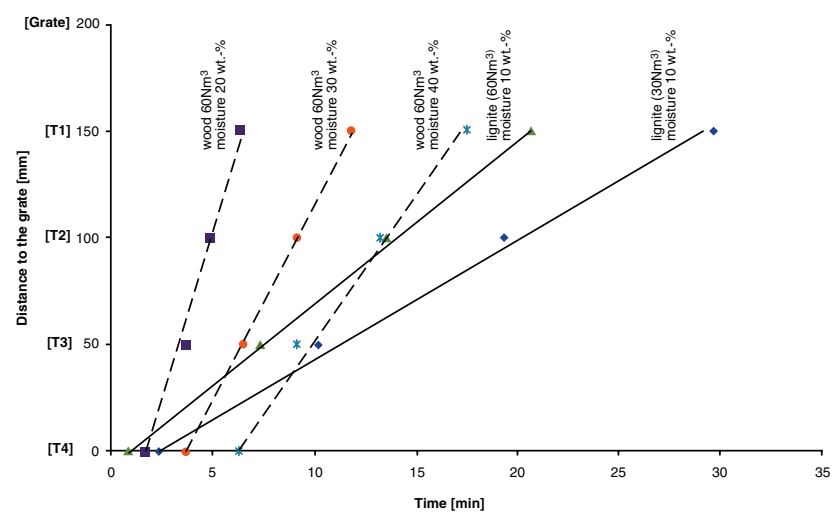

Figure 11. Investigations of the burning behaviour in the batch-reactor with the reaction front velocity.

wood chips with variations in fuel moisture. The influence of altered experimental conditions is obvious from the reaction front velocity. The reaction front velocity increases for coal with 


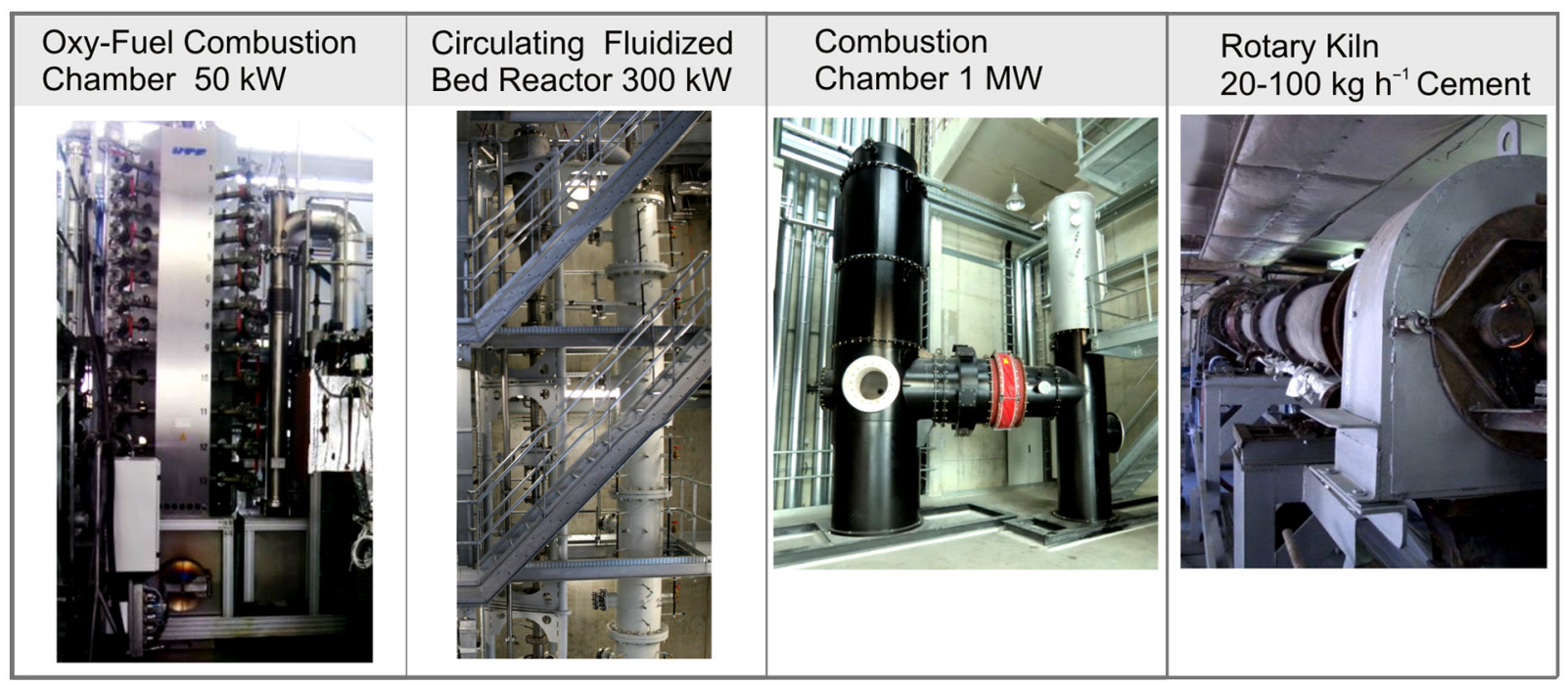

Figure 12. Pilot scale facilities loxy-fuel combustion chamber $50 \mathrm{~kW}$, circulating fluidized bed reactor, 1 MW combustion chamber and a rotary kiln.

the increase in the amount of primary air supplied, while it decreases with the increase in moisture content for the wood chips, for which the time to ignition increases due to the longer drying period.

With the aid of a Batch-Reactor (at the so-called technical testing/technical scale) it is possible, for example, through variable air amounts or air gradients (e.g. Ludewig, 2011), to control the stages of solid matter conversion (pyrolysis, gasification and combustion) and to manage the thermal treatment situation. Fuel behaviour and process control can be investigated for each type of fuel (i.e. different fuels with variation of fuel moisture, or the bulk density and particle size).

In addition to technical-scale plants, pilot-scale plants can also be used for the characterization of SRF. Data from this characterization can be transferred to real processes, but the effort (time and cost) to achieve results is very high. In Figure 12, examples of various pilot scale plants are shown, including a dust-firing oxyfuel plant $(50 \mathrm{~kW})$ with recirculation, which also allows studies of the fuel behaviour under oxy-fuel conditions (Weigl, 2009; Wilhelm, 2010), a circulating fluidized bed boiler, a combustion chamber with $1 \mathrm{MW}$ and a rotary cement kiln (AIF, 2009).

\section{Ash composition and ash melting behaviour}

In Figure 13, studies of the ash melting behaviour of various fuels and materials are presented. The comparison shows that the melting behaviour varies widely. Large differences in temperatures at characteristic states butalsoin the differencebetween the shrinkagetemperature and flow temperature can be recognized. However, for the fuels SRF and pure pulp investigated here, the difference between the shrinkage temperature and flow temperature is only about $100 \mathrm{~K}$ and $131 \mathrm{~K}$, respectively, whereas for mineral basalt and for the coal sample, the difference is approximately $203 \mathrm{~K}$ and $213 \mathrm{~K}$, respectively.
The characteristic temperatures determined in an ash melting furnace (referring to DIN 51730 (DIN, 2007)) are initial indicators of the slagging and fouling behaviour of the fuel ash. The ash composition is to be considered, especially in ashes which are composed of heterogeneous materials, as they can only melt partially, which cannot, in the vast majority of cases, be demonstrated through optical methods of measurement.

In the investigations mentioned here, additives altered the ash melting behaviour of pure pulp. It has been found that some additives have an influence on the ash chemistry, which means that a change takes place in the chemical bonds between different elements found in the ash. Other additives only affect the ash melting behaviour as structural components which means that the pressed body remains dimensionally stable. This is observed as the ash material flows out of the compact pressed body (Bernhardt et al., 2011).

The analysis of the fuel ash elemental composition is another indication of slagging and fouling behaviour. It should be noted that the particular composition of each ash depends on the process, and thus on the respective conditions, such as the temperature and the availability of oxygen. Investigations of ash in the laboratory are standardized as described above; that is, the ashes are processed (ground) and analysed under standardized conditions.

Figure 14 shows a comparison of the elements $\mathrm{Ca}-\mathrm{Si}-\mathrm{Al}$ in an SRF ash from a technical-scale plant (Batch-Reactor).The ash is divided into different grain sizes (coarse, medium and fine fraction) and the analysed elements are shown. Also displayed is the average value calculated from the different grain size averages.

Differences in the chemical composition of the ash in this SRF are apparent and are attributed to the grain size. First, this indicates the heterogeneity of the fuel, and thus the ash. In addition, this context shows that as described above, the slagging and fouling behaviour, due to different melting points of the ash 


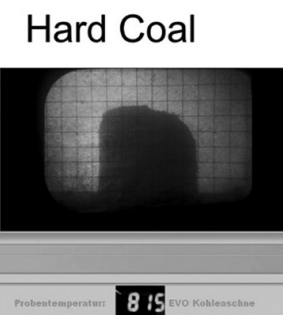

SRF
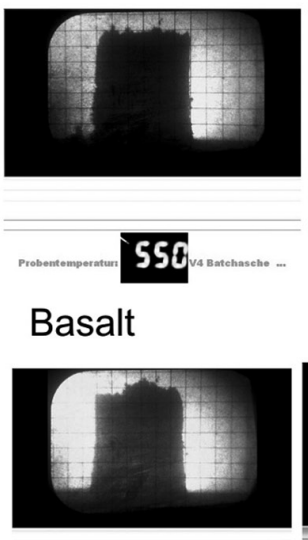

800

Pure pulp

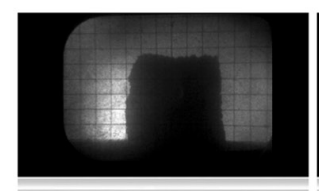

550
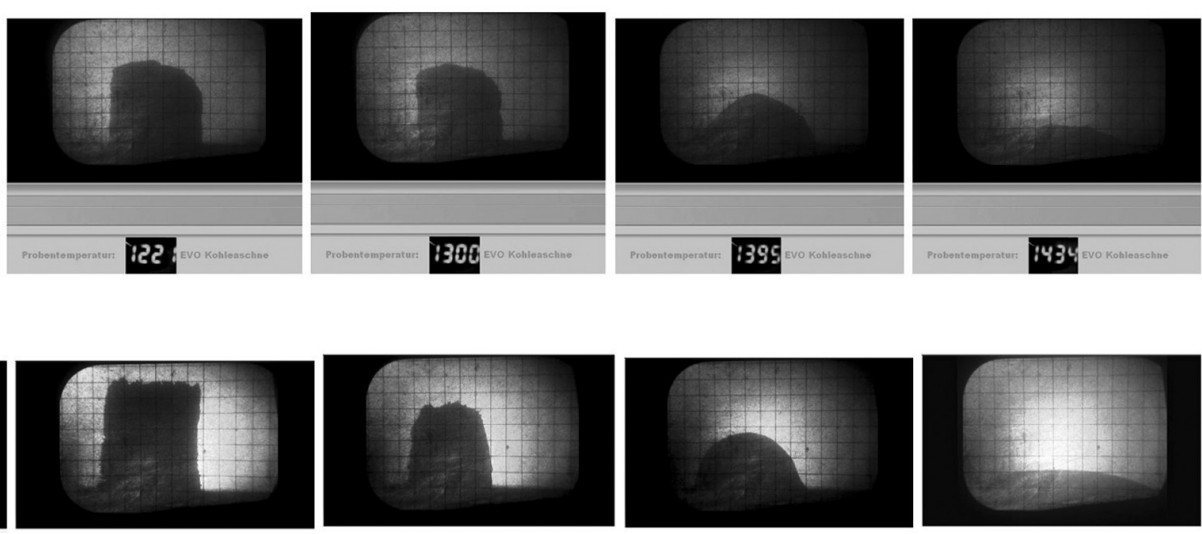

1254

IIEE
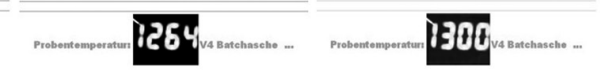

1200
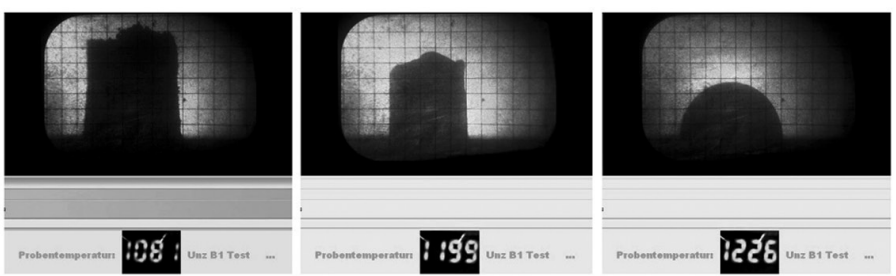

एसंद

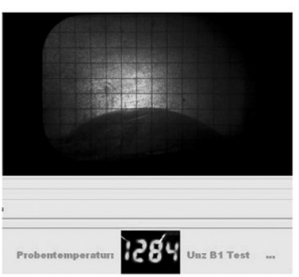

1284

Figure 13. Ash melting behaviour of different fuels and basalt (left to right (referring to DIN 51730 (2007)): initial state, shrinkage-temperature, deformation-temperature, hemisphere-temperature and flow-temperature).

components, must be further investigated beyond standardized methods of ash melting behaviour and ash analysis both in the laboratory, in application-based technical and pilot-scale plants, in order to gather information about the behaviour of the fuel and the ash in real processes.

At the laboratory scale, other opportunities are available for ash particle analysis (Galbreath et al., 1996; Laursen and Frandsen, 1997) and for the determination of ash melting behaviour (Gilbe et al., 2008).

In (Dunnu et al., 2010; Kupka, 2009), for example, the applicability of ratios used to describe coal combustion was investigated for the characterization of SRF ashes, for example the base-to-acid ratio

$$
R_{B / A}=\frac{\mathrm{Fe}_{2} \mathrm{O}_{3}+\mathrm{CaO}+\mathrm{MgO}+\mathrm{K}_{2} \mathrm{O}+\mathrm{Na}_{2} \mathrm{O}}{\mathrm{SiO}_{2}+\mathrm{Al}_{2} \mathrm{O}_{3}+\mathrm{TiO}_{2}}
$$

and the slag viscosity index

$$
S_{R}=\frac{\mathrm{SiO}_{2}}{\mathrm{SiO}_{2}+\mathrm{Fe}_{2} \mathrm{O}_{3}+\mathrm{CaO}+\mathrm{MgO}}
$$

Calculations from the ash composition of various SRF fuels - used tyres, waste wood, sewage sludge, plastics and paper - and fossil fuels are determined and compared with each other. Tendencies for the applicability of the calculations were determined.

The previously discussed relationships, however, show that the results of calculation-based assessments of the slagging and fouling behaviour by the authors are not applicable criteria especially for alternative fuels (Pohl et al., 2011).

\section{Slagging, fouling, and corrosion behaviour of fuels}

In terms of slagging, fouling, and corrosion behaviour of fuels, it is necessary to determine corrosion properties, namely the solid 

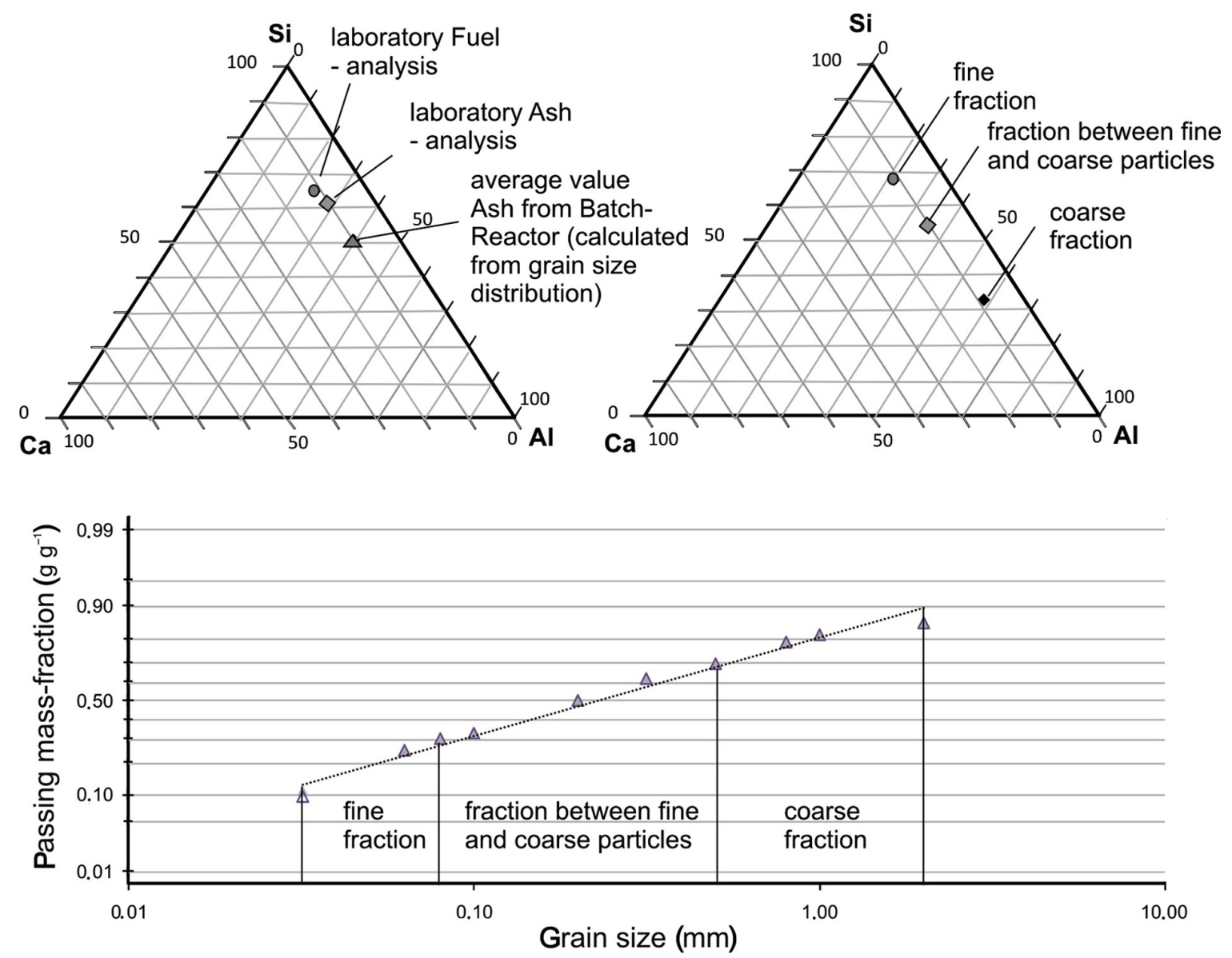

Figure 14. Comparison of the composition (Si, Al, Ca) of SRF fuel and of different particle of the SRF-ash and the associated grain size distribution of the ash from investigations in the batch-reactor.

and liquid components released, as well as the gaseous components in the flue gas, through isokinetic sampling of these components. Currently, different methods are being tested on the pilot scale, the technical scale, and in industrial plants (Figure 15). For example, it is also possible to further develop proven methods on the industrial scale (e.g. Spiegel et al., 2008) to assess the slagging, fouling, and corrosion behaviour of fuels, before they are used in an industrial plant, with the aid of technical and pilotscale plants (Pohl et al., 2010), a possibility that will be discussed with examples in the following.

For isokinetic sampling, distinctions will be made between the amounts of the physical (solid, liquid) and material (silicates, oxides, chlorides, sulfates, hydroxides, etc.) components of the different particles in the flue gas, depending on the sampling position (i.e. measurement opening in the boiler) and the isokinetic gas temperature.

The different particle types (coarse and fine particles, especially molten salts relevant to corrosion (Pohl et al., 2010)) form significant sediment structures on the so-called fouling layer probe. Mineralogical evaluation of the structures and the chemical data from point and small-area measurements of the deposited particles give reason for a differentiated evaluation of the flue gas particles on the fouling layer at the sampling position.

Figure 16 shows the results of a surface probe measurement carried out in a Batch-Reactor as an SRF was being used. The wire grid of the probe is investigated with a scanning electron microscope (SEM), so that the individual separated particles are visible. More results from the wire grid probe measurements of large-scale use in a coal-fired fluidized bed reactor, waste-fired plants and in the Batch-Reactor, have been published for example in (Beckmann et al., 2009; Pohl et al., 2010). Figure 16 further shows a chemical and mineralogical assessment of these significant sedimentation structures. The chemical composition of the point and small-area measurements of the deposited particles is shown with the help of spider-web diagrams, where the composition of the particles is always shown with the reference composition of these elements in the fuel.

In the upper diagram, the particle analysis is presented, in which the fuel composition of the selected major elements is very similar. In the bottom diagram, a large shift towards sodium is evident, with a simultaneous decrease in the relative proportions of calcium and silicon. 


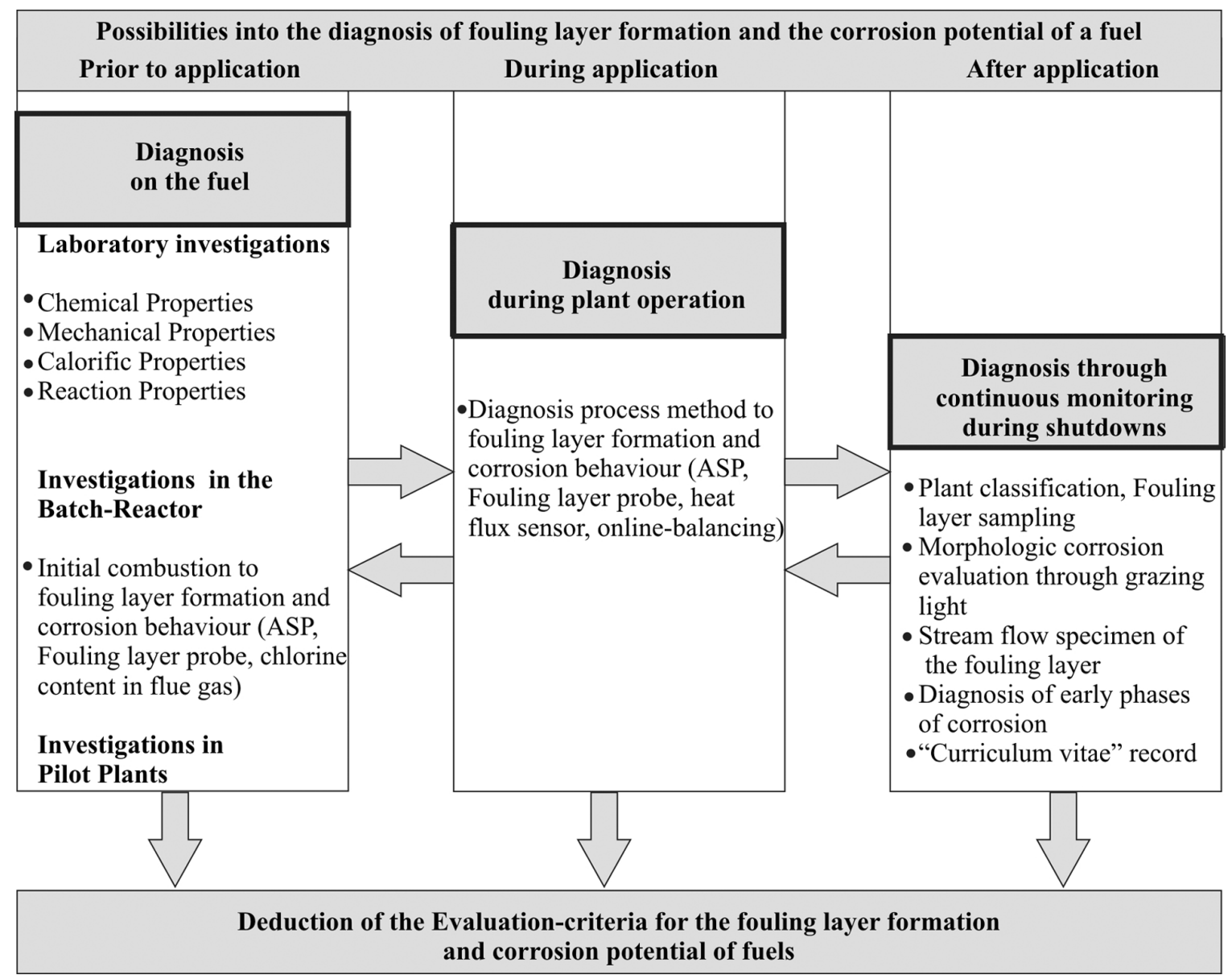

Figure 15. Possibilities of the diagnosis of fouling layer formation and the corrosion potential.

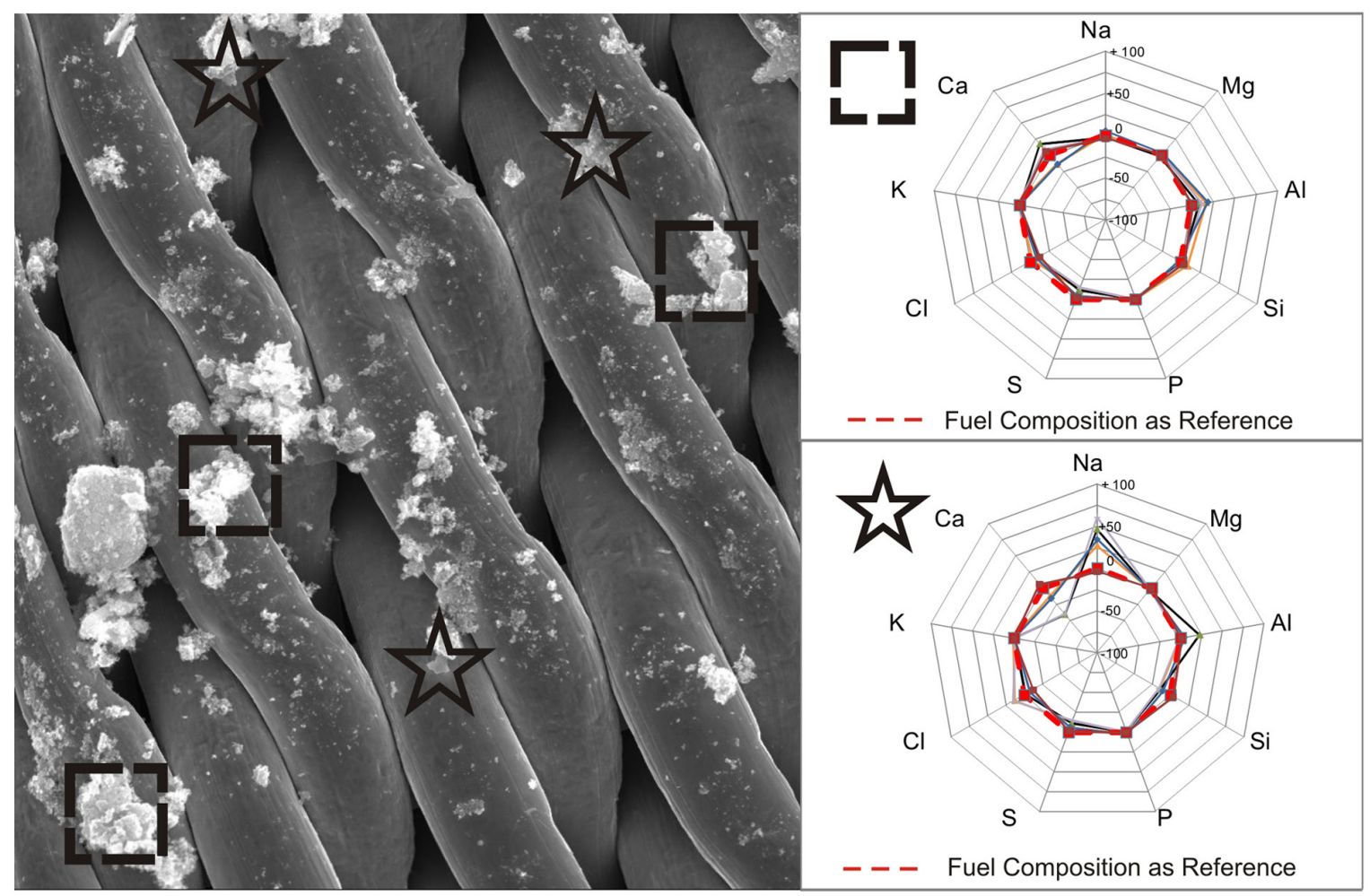

Figure 16. Wired grid for the particle measurement, sampling in the batch-reactor (fuel: SRF). 
The differences in the chemical composition of the particles selected here can also be seen visually in Figure 16. To ensure the scientific validity of conclusions about the slagging, fouling and corrosion behaviour of the fuels, more measurements and studies comparing effects in industrial plants are necessary. For this reason, no assessment of the results of the wire grid probe measurements will be given at this time although it should be noted that a differentiated assessment of the particles participating in the surface structure is needed to further understand slagging and corrosion behaviour.

From a materials point of view, there is a wide range of elements relevant to corrosion, especially the different corrosion effects of chlorine and sulfur compounds, which depend on the temperature and the change of the aggregate state between solid, liquid, and gaseous states. Thus, the total chlorine content, for example, is insufficient as a quality criterion for refuse-derived fuels and biomass. Similar to indicators of slagging and fouling behaviour, there are also indicators to aid in corrosion evaluation of a fuel, for example, the sulfur to chlorine ratio (Bachhiesl et al., 2001). Once again, it is pointed out that these indicators are not applicable as quality criteria because of the complex relationships among corrosion mechanisms.

The chlorine bonding plays an important role in release of chlorine and in deposit formation. Chlorine, as well as the alkali metals, are important for complex reactions and phase transitions and are naturally bound inside the biomass. Potassium, for example, is a nutrient responsible for wood growth. Additionally, the heavy metals found in high concentrations in refuse-derived fuels should be considered.

In the flue gas, the high amount of $\mathrm{HCl}$ can be evaluated as a negative quality. However, the distribution of chlorine in the flue-gas as both $\mathrm{HCl}$ and chloride salts very much depends on the fuel composition and the operational conditions and can fluctuate between widely different limits.

Decisive for the corrosion potential is whether the $\mathrm{HCl}$ is carried out with the flue gas or if it reacts with the alkali and heavy metal compounds, which leads to salt deposition.

High fractions of $\mathrm{SO}_{2}$ and/or $\mathrm{SO}_{3}$ are evaluated as positive (Kautz and Warnecke, 2003). $\mathrm{SO}_{2}$ and especially $\mathrm{SO}_{3}$ are considered active reaction partners in comparison with dissolved or crystallized chlorine, resulting in sulfatization of species in the flue gas; sulfates also have a mild influence on corrosion (Hjörnhede, 2009). In practical applications, this influence has not been proven for the combustion of difficult fuels and is possibly limited by kinetic constraints.

Examples of other publications in the field of slagging, fouling, and corrosion are (Bryers, 1996; Frandsen, 2011; Mikkanen, 2000; Spiegel et al., 2010; Zeuthen et al., 2007). These references deal with the investigation of the released particles and corrosion mechanism.

\section{Monitoring during operation}

In addition to the characterization of alternative fuels prior to large-scale industrial use, it is necessary to monitor their behaviour during application. This is done, for example, through emission measurements $\left(\mathrm{NO}_{\mathrm{x}}, \mathrm{SO}_{2}, \mathrm{HCl}\right)$ or the systems control, which controls the process based on process variables, and therefore monitors the fuel and its behaviour in the combustion facility.

For the evaluation of actual operating conditions at plants that mainly use heterogeneous fuels, such as waste-based fuels and biomass, it is essential to know the mass flow rate and the LHV, as well as the chemical fuel composition. During operation of the plant, this information is usually not sufficiently accurate, or is completely unavailable (sampling and sample preparation).

With the help of mass and energy balances, it is possible to determine these important parameters during operation (Horeni, 2007). The practicality, for example, the method of online balancing was and is currently being investigated in several plants (Horeni et al., 2007); for example, as part of investigations of the corrosion potential of fuels (Pohl et al., 2008) or as part of plant optimization (Busch et al., 2011) in interaction with different control mechanisms and other measurement methods (heat-flow measurements; see also (Grahl and Beckmann, 2010), probe measurements/ash to salt proportions; see also (Spiegel, 2006).

Exemplarily a comparison of investigations to determine the mass flow rate and the LHV is shown in Figure 17. The waste mass flow, determined by a weighing device, is averaged over 1 $\mathrm{h}$, because of the discontinuous fuel supply into the dosing device of the grate facility. In contrast, the balanced waste mass flow was calculated based on 1 min averages. Deviations in the values result from the averaging of the crane balance measurement. Comparing the values for an extended period shows very small deviations in these two measurements. This leads among others to the conclusion that the online balance value agrees with the real fuel mass flow.

Furthermore, a comparison of LHV determined through different methods is shown. These were determined by mass and energy balances, or through the fuel composition with the help of heating value equations (Pohl et al., 2008). The equation-based heating value agrees well with the online balance heating value. The fuel composition (carbon, oxygen, and water content) required for the heating value was calculated by material balances with the assumption of a constant $\mathrm{C} / \mathrm{H}$-ratio (see above) and is shown in the lower diagram in Figure 17.

Similar studies to determine the fuel composition and caloric value were carried out with consideration for the biogenic carbon content of fuels in Fellner et al. (2007).

In relation to fuel-monitoring during operation, another possibility to get information about the deposits depending on the fuel and operating conditions is the method of measuring the heat flux density (Grahl and Beckmann, 2010). For signal analysis, the strategy is to draw conclusions from the periodic fluctuations of the measuring signal, which result from fluctuations in the combustion process, about the characteristics of the deposit, such as layer thickness, heat conductivity, and thermal diffusivity. The deposit damps the fluctuations in comparison with the 'clean' 

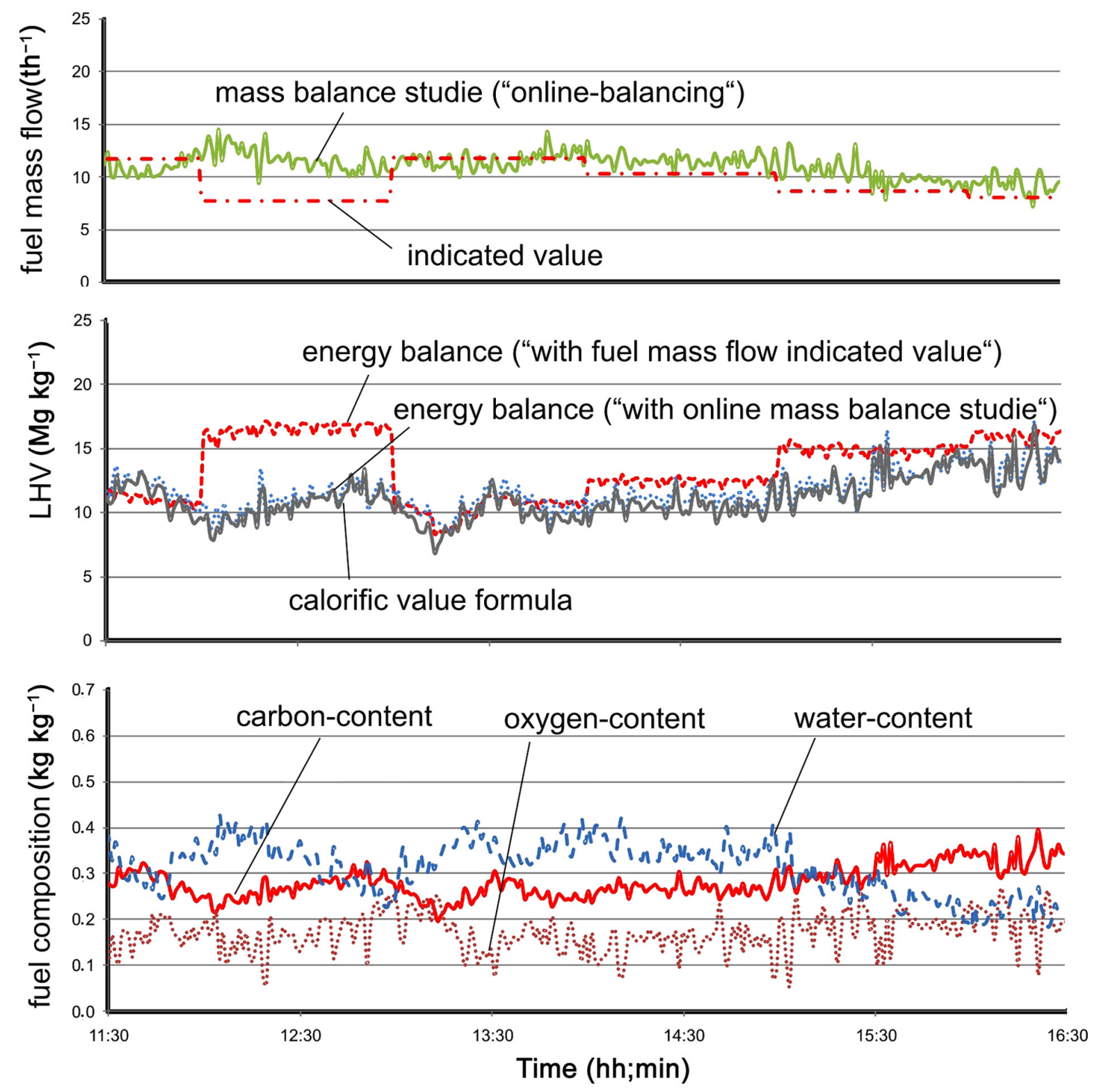

Figure 17. Comparison of the fuel mass flow and of different fuel properties, investigated with process-data (mass balance study - calculated with 'online-balancing').

membrane wall state, and that results in a phase shift in the measuring signal. The damping and the phase shift are influenced by the deposition layer thickness and thermal properties of the layer (heat conductivity, density, heat capacity, ... . ). A mathematical model derived from known fundamentals of heat conductivity during periodic fluctuations is used to estimate the deposit characteristics from the measurement values. The information attained is useful for online measurement of deposits and supports the operators in process control optimization and setting cleaning cycles, and provides an orientation for assessments of the deposition layer's corrosion behaviour. Diverse applications of this measurement and analysis method in other areas with similar boundary conditions are practicable.

In addition to the laboratory methods to characterize a fuel described above, characterization during the application of SRF on the technical and pilot scales, as well as real plants, are of great importance for fuel assessment, particularly for heterogeneous fuels such as SRF.

\section{Conclusion and outlook}

The waste treatment, particularly the thermal treatment of waste has changed fundamentally in the last 20 years - from facilities solely dedicated to the thermal treatment of waste to facilities, which in addition to ensuring safe plant operation also fulfill very ambitious criteria with regard to emission reduction, resource recovery and energy efficiency as well. This has resulted in the view of waste as an alternative fuel source.

Methods of fuel characterization are not readily transferable, due especially to the heterogeneity of SRF compared to regular 
fuels. In sampling, sample preparation and analysis in the laboratory, adaptations to these methods are necessary.

In addition to standard laboratory methods, further studies of fuel characterization are necessary, especially investigations of practical applications at technical, pilot and industrial scales.

Besides the usual methods for standard fuels to determine a fuel's reaction properties, thermo-gravimetric analysis and drop tube reactor investigation, investigations in Batch-Reactors have been established, in which larger amounts of SRF can be investigated in the original grain size.

Due to low melting temperatures, components in SRF, compared to regular fuels, contain a very high amount of corrosive ingredients, leading to slagging, fouling and corrosion. New methods to characterize the release of corrosive components, such as particle-measuring probes, have been developed or are currently under development.

Methods such as 'online balancing', heat flux measurement and particle measurement, are necessary and are described in the article, because they allow investigations of the effects of SRF use during the use of SRF in power plants.

These newly developed methods are used in addition to common methods of fuel characterization, but can also be used in plant energy efficiency improvements and in further advancements in this field, for example, in investigations of circulation elements in power plants under oxy-fuel conditions (Thiel et al., 2011).

\section{Abbreviations}

$\begin{array}{ll}\text { ar } & \text { as received } \\ \text { ASP } & \text { ash-salt-proportion } \\ \text { c } & \text { carbon content } \\ \text { C/H-ratio } & \text { carbon to hydrogen ratio } \\ \text { C/O-ratio } & \text { carbon to oxygen ration } \\ \text { daf } & \text { dry and ash free } \\ \text { DIN } & \text { German Standards Organization } \\ \text { ISO } & \text { International Standards Organization } \\ \text { LHV } & \text { lower heating value } \\ \text { o } & \text { oxygen content } \\ R_{\mathrm{B} / \mathrm{A}} & \text { base to acid ratio } \\ \text { SEM } & \text { scanning electron microscope } \\ S_{\mathrm{R}} & \text { slag viscosity index } \\ \text { SRF } & \text { solid recovered fuel } \\ \text { TGA } & \text { thermo gravimetric analysis } \\ \text { W } & \text { water content. }\end{array}$

\section{Funding}

This research received no specific grant from any funding agency in the public, commercial, or not-for-profit sectors.

\section{References}

AIF (AiF-Forschungsvorhaben) (2009) Substitution von Regelbrennstoffen durch Ersatzbrennstoffe [Substitution of standard fuels through RDF]. AiF-Nr. 14894 BG. [Beckmann, M., Bauhaus-Universität Weimar; Scholz, R., Technische Universität Clausthal, Institut für
Energieverfahrenstechnik und Brennstofftechnik; Flamme, S., Institut für Abfall, Abwasser, Site und Facility Management e. V., Ahlen; Seifert, H., Forschungszentrum Karlsruhe, Institut für Technische Chemie, Eggenstein-Leopoldshafen].

Bachhiesl M, Tauschitz J, Zefferer H, et al. (2001): Untersuchung zur thermischen Verwertung von Biomasse und heizwertreichen Abfallfraktionen als Sekundärbrennstoffe in Wärmekraftwerken [Investigation for thermal processing of biomass and calorific waste fractions as fuels in thermal power plants]. Schriftenreihe der Forschung im Verbund Band 73. Wien, 2001.

Beckmann M and Scholz R (1999) Energetische Bewertung der Substitution von Brennstoffen durch Ersatzbrennstoffe bei Hochtemperaturprozessen zur Stoffbehandlung [Energy assessment of the substitution of standard fuels through $\mathrm{RDF}$ in high temperature processes for waste treatment]. Teil 1: ZKG International 52 (1999) Heft 6, S. 287-303. Teil 2: ZKG International 52 (1999) Journal 8, S. 411-419.

Beckmann M and Scholz R (2006) Biomasse- und Ersatzbrennstoffe als schwierige Brennstoffe [Biomass fuels and RDF as difficult fuels]. In: (Hrsg. K-J Thomé-Kozmiensky and M Beckmann) Energie aus Abfall - Band 1. Berlin: TK Verlag Karl Thomé-Kozmiensky, S.105-137.

Beckmann M, Horeni M, Scholz, R, et al. (2003) Notwendigkeit der Charakterisierung von Ersatzbrennstoffen [Need for characterization of RDF]. In: (Hrsg. KJ Thomé-Kozmiensky) Ersatzbrennstoffe 3- Immissions- und Gewässerschutz, Qualitätssicherung, Logistik und Verwertung, Deponierung der Schwerfraktion. Neuruppin, Germany: TK-Verlag Thomé-Kozmiensky.

Beckmann M, Pohl M, Gebauer K, et al. (2009): Characterisation of refuse derived fuels in view of the corrosion potential. Proceedings of the International Conference on Incineration and Thermal Treatment Technologies - IT3, 18-22 May 2009, Cincinnati (USA). Pittsburgh, PA: A\&WMA.

Bernhardt D, Pohl M, Gebauer K, et al. (2011) Biogenous residues for the use as wood pellet equivalent fuels. In: Proceedings of the International Conference on Thermal Treatment Technologies \& Hazardous Waste Combustors - IT3, 10-13 May 2011, Jacksonville (USA). Pittsburgh, PA: A\&WMA.

BGS (Gütegemeinschaft Sekundärbrennstoffe und Recyclingholz e.V.) (ed.) (2008) RAL-GZ 724. Münster: BGS.

Bleckwehl S, Kolb T, Seifert H, et al. (2004) Verbrennungsverhalten von MBA-Fraktionen [Combustion behaviour of MBA fractions.]. In: (Hrsg. KJ Thomé-Kozmiensky) Ersatzbrennstoffe 4. Neuruppin: TK Verlag Karl Thomé-Kozmiensky.

Bleckwehl S, Leibold H, Walter R, et al. (2002) Einfluss der zeitlichen und örtlichen Luftstufung auf das Abbrandverhalten von stückigem Brennstoff in einem Batch-Prozess [Influence of temporal and local air staging on the combustion behavior of fuels in a batch process]. Wiesbaden: GVCJahrestagung.

Boie W (1957) Vom Brennstoff zum Rauchgas [From the fuel to the flue gas]. Leipzig: B.G. Teubner Verlagsgesellschaft.

Busch M, Martin JJE, Bardi S, et al. (2011) Betriebsartenkonzepte für die Abfallverbrennung [Operating modes for waste incineration]. In: (Hrsg. KJ Thomé-Kozmiensky and M Beckmann) Energie aus Abfall - Band 8. Neuruppin: TK Verlag Karl Thomé-Kozmiensky, pp. S. 83-91.

Bryers RW (1996) Fireside slagging, fouling, and high-temperature corrosion of heat-transfer surface due to impurities in steamraising fuels. Progress in Energy and Combustion Science 22: 29-120.

DIN (1997) DIN 51719: Prüfung fester Brennstoffe - Bestimmung des Aschegehaltes [Testing of solid fuels-Solid mineral fuels-Determination of ash content]. Berlin, Germany: Deutsches Institut für Normung e.V.

DIN (2007) DIN 51730: Prüfung fester Brennstoffe - Bestimmung des Asche-Schmelzverhaltens [Testing of solid fuels - Determination of fusibility of fuel ash]. Berlin, Germany: Deutsches Institut für Normung e.V.

DIN (2010) DIN EN 14 775: Feste Biobrennstoffe - Bestimmung des Aschegehaltes [Solid biofuels - Determination of ash content]. Berlin, Germany: Deutsches Institut für Normung e.V.

DIN (2011) DIN EN 15 403: Feste Sekundärbrennstoffe - Bestimmung des Aschegehaltes [Solid recovered fuels - Determination of ash content]. Berlin, Germany: Deutsches Institut für Normung e.V.

Dunnu G, Maier J and Scheffknecht G (2010): Ash fusibility and compositional data of solid recovered fuels. Fuel 89: 1534-1540.

Eckardt S (2005) Anforderungen an die Aufbereitung von Siedlungs- und Produktionsabfällen zu Ersatzbrennstoffen für die thermische Nutzung in Kraftwerken und industriellen Feuerungsanlagen [Requirements for the 
treatment of municipal and production waste into RDF for use in thermal power plants and industrial furnaces]. In: Schriftenreihe des Instituts für Abfallwirtschaft und Altlasten der Technischen Universität Dresden. Pirna, Germany: Beiträge zu Abfallwirtschaft/ Altlasten, Bd. 41.

EdDE (ed.) (2003): Substitution von Primärbrennstoffen durch Sekundärbrennstoffe [Substitution of primary fuels through RDF]. Köln, Germany: Entsorgergemeinschaft der Deutschen Entsorgungswirtschaft EdDE (Hrsg.).

Fellner J, Cencic O and Rechberger H (2007) A new method to determine the ratio of electricity production from fossil an biogenic sources in waste-to-energy plants. Environmental Science and Technology 41(7): S.2579-2586.

Frandsen FJ (2011) Ash Formation, Deposition and Corrosion when Utilizing Straw for Heat and Power Production. Doctoral Thesis, DTU Chemical Engineering, Technical University of Denmark.

Galbreath K, Zygarlicke C, Casuccio G, et al. (1996) Collaborative study of quantitative coal mineral analysis using computer-controlled scanning electron microscopy. Fuel 75(4): 424-430.

Gilbe C, Lindström E, Backmann R, et al. (2008) Predicting slagging tendencies for biomass pellets fired in residential appliances: a comparison of different prediction methods. Energy \& Fuels 22: 3680-3686.

Gleis M and Raesfeld U (2011) Ersatzbrennstoff-Kraftwerke in Deutschland [Substitute fuel power plants in Germany]. In: (Hrsg. KJ ThoméKozmiensky and M Beckmann) Erneuerbare Energien - Band 6. Neuruppin: TK Verlag Karl Thomé-Kozmiensky, pp. S. 283-314.

Grahl S and Beckmann M (2010) Wärmestromdichtemessung zur Belagsbestimmung [Heat flux density measurement for determining deposits]. In: (Hrsg. M Beckmann and A Hurtado) Kraftwerkstechnik - Sichere und nachhaltige Energieversorgung -. Neuruppin: TK Verlag Karl Thomé-Kozmiensky, Bd. 2, pp. S.727-742.

Gumz W (1962) Kurzes Handbuch der Brennstoff- und Feuerungstechnik [Short Handbook of Fuel and Combustion Technology]. 3. Auflage. Berlin: Springer-Verlag.

Haas J, Tamura M and Weber R (2001) Characterisation of coal blends for pulverised fuel combustion. Fuel 80: 1317-1323.

Hannes JP and Wachenhausen M (1999) Mitverbrennung von 'Refuse Derived Fuel' in kohlegefeuerten Kraftwerkskesseln [Co-firing of 'Refuse Derived Fuel' in coal-fired power plant boilers.]. In VDI-Berichte 1492. Düsseldorf: VDI Verlag GmbH, pp. S.381-386.

Hjörnhede A (2009) ChlorOut: reduction of corrosion in waste wood fired boilers. In: (Hrsg. M Born): Dampferzeugerkorrosion. Freiberg: Verlag SAXONIA Standortentwicklungs- und -verwaltungsgesellschaft mbH.

Hoenig V (1998) Emissionen beim Einsatz von Sekundärbrennstoffen in Drehofenanlagen der Zementindustrie [Emissions in the use of RDF in rotary kilns of the cement industry]. In: Proceedings ,Einsatz von industriellen und kommunalen Abfällen im Zementherstellungsprozess, OpoleJarnoltówek, 15-16 Oktober 1998, pp. S.45-54.

Horeni M (2007) Möglichkeiten für die energetische Optimierung von Müllverbrennungsanlagen - Entwicklung, Erprobung und Validierung eines Online-Bilanzierungsprogramms [Possibilities for optimizing energy from waste incinerators]. Papierfliegerverlag Clausthal-Zellerfeld, Dissertation.

Horeni M, Beckmann M, Fleischmann H, et al. (2007) Ermittlung von Betriebsparametern in Abfallverbrennungsanlagen als Voraussetzung für die weitere Optimierung [Determination of operating parameters in waste incineration plants as a requirement for the further optimization]. In: (Hrsg. KJ Thomé-Kozmiensky and M Beckmann) Energie aus Abfall - Band 2. Berlin: TK Verlag Karl Thomé-Kozmiensky, pp. S.213-229.

IEVB (ed.) (2011) http://www.ievb.tu-clausthal.de/de/ausstattung/speziellemethoden-zur-brennstoffcharakterisierung/ (accessed 15 June 2011).

Kautz K and Warnecke R (2003) Der Einsatz rauchgasseitiger Additive vor dem Hintergrund der verschieden starken Korrosionsund Verschmutzungsgefährdungen unterschiedlich ausgelegter Müllheizkraftwerke [The use of additives in different Waste to energy plants]. In: (Hrsg. M. Born) Dampferzeugerkorrosion. Freiberg: Verlag SAXONIA Standortentwicklungs- und -verwaltungsgesellschaft $\mathrm{mbH}$, pp. S.279-289.

Kehl P, Scharf K-F, Scur P, et al. (1998) Die Betriebsergebnisse aus den ersten 30 Monaten mit der neuen Ofenlinie 5 im Zementwerk Rüdersdorf [The operating results of the first 30 months with the new kiln line 5 in the cement plant Rüdersdorf]. Zement-Kalk-Gips ZKG International 51(8): S.410-426.

Kupka T (2009) Ash Deposition Problems during Co-firing of Alternative Fuels in Coal-fired Power Plants. Dissertation TU Clausthal.

Kupka T, Mancini M, Irmer M, et al. (2008) Investigation of ash deposit during co-firing of coal with sewage sludge, saw-dust and refuse derived fuel. Fuel 87: 2824-2837.

Laursen K and Frandsen FJ (1997) Classification system for ash deposits based on SEM analysis. In: Proceeding of Engineering Foundation Conference on Impact of Mineral Impurities in Solid Fuel Combustion, Kona, HI, USA, 2-7 November 1997. New York, NY: Kluwer Academic/ Plenum Publishers.

Ludewig S (2011) Prozessmodellgesteuerte Optimierung von Primärmaßnahmen zur NOx-Minderung in Rostfeuerungen bei Einsatzstoffen mit unbekannter, zeitlich veränderlicher Zusammensetzung [Model-driven optimization of the process to reduce NOx emissions in grate when using Fuels with unknown, time-varying composition]. Papierfliegerverlag Clausthal-Zellerfeld, Dissertation.

Mikkanen P (2000) Fly Ash Particle Formation in Kraft Recovery Boilers. Thesis, VTT Publication 421, Technical Research Centre of Finland, Espoo.

Pohl M, Beckmann M and Gebauer K (2008) Characterisation of refuse derived fuels in view of the fuel technical properties. In: Proceedings of the 8th European Conference on Industrial Furnaces and Boilers (INFUB-8), 25-28 March 2008, Vilamoura, Algarve (PT). CD-ROM. Essen, Germany: VGB PowerTech e.V.

Pohl M, Bernhardt D, Ncube S, et al. (2010) Diagnostic methods into the corrosion potential of alternative fuels i.e. biomass and refuse derived fuels. In: Proceedings of the Conference on Impacts of Fuel Quality on Power Production and Environment, 29 August-3 September 2010, Saariselkä (FIN). Palo Alto, CA: Electric Power Research Institute, Inc.

Pohl M, Bernhardt D, Beckmann M, et al. (2011): Brennstoffcharakterisierung zur Bewertung des Korrosionsrisikos [Fuel characterization to evaluate the risk of corrosion]. In: (Hrsg. M Born) Dampferzeugerkorrosion. Freiberg: Verlag SAXONIA Standortentwicklungs- und -verwaltungsgesellschaft mbH, pp. S.67-82.

Porteiro J, Patiño D, Collazo J, et al. (2010) Experimental analysis of the ignition front propagation of several biomass fuels in a fixed-bed combustor. Fuel 89: 26-35.

Sander HJ (2000) Mitverbrennung von Ersatzbrennstoffen aus aufbereiteten Siedlungsabfällen [Co-firing of RDF from municipal solid waste]. In: VDI Bildungswerk 430403, 13-14 March 2000, Düsseldorf. Düsseldorf, Germany: UDI-Verlag.

Schade-Dannewitz S, Poerschke J and Döring S (2009) Pressbohrkernmethode - ein neues Verfahren zur Probenentnahme von Ersatzbrennstoffen [Pressbohrkernmethode - a new method for the sampling of RDF]. In: (Hrsg. B Bilitewski, P Werner, S Rotter, et al.) Tagungsband EBSAnalytik 2, Qualitätssicherung und Inputkontrolle - Band 60. Dresden: Eigenverlag des Instituts für Abfallwirtschaft und Altlasten der TU Dresden, pp. S.77-96.

Scheurer W, Richers U, Maier J, et al. (2000) Gegenwärtiger Stand und Perspektiven der Mitverbrennung in deutschen Kraftwerken [Current status and prospects of co-combustion in German power plants]. In: Wege des Abfalls. VDI-Berichte 1540, Düsseldorf: VDI Verlag GmbH, pp. S.233-248.

Scholz R and Harnaut T (2002) Energetische Bewertung und Optimierung von Verfahren der thermischen Abfallbehandlung am Beispiel des Klinkerbrennprozesses und des Schrotteinschmelzens [Energy assessment and optimization of processes of thermal waste treatment]. In: 13. DVV-Kolloquium 'Thermische Verfahren der Abfallbehandlung - Entwicklungen, Optimierung, Bewertung', 23-24 September 2002 Weimar. Weimar: Universitasverlag.

Scur P (1999) Potentiale und Grenzen des Einsatzes von Ersatzbrennstoffen in der Zementindustrie [Potentials and limitations of the use of RDF in the cement industry]. In: (Hrsg. K Wiemer and M Kern) Bio- und Restabfallbehandlung III, biologisch - mechanisch -thermisch. Witzenhausen: Baeza-Verlag.

Skutan S and Brunner PH (2006) Stoffbilanzen mechanisch-biologischer Anlagenzur Behandlung von Restmüll (SEMBA) [Material balances mechan- 
ical-biological waste treatment plants]. Studie für das Bundesministerium für Land und Forstwirtschaft, Umwelt und Wasserwirtschaftund der Umweltbundesamt GmbH in Österreich. Wien: TU Wien.

Sommer M and Ragossnig A (2011) Energy from waste in Europe: an analysis and comparison of the EU 27. Waste Management \& Research 29(10): 69-77.

Spiegel W (2006) Analyse des Rohgases und der Kesselablagerung zur Beurteilung der Ersatzbrennstoffqualität [Analysis of the flue gas and the boiler deposits to assess the quality of substitute fuel]. In: (Hrsg. KJ Thomé-Kozmiensky and M Beckmann) Energie aus Abfall, 2006, Band 1. Neuruppin: TK Verlag Karl Thomé-Kozmiensky.

Spiegel W, Herzog T, Jordan R, et al. (2008): Korrosion in Biomasseverbrennungsanlagen [Corrosion in biomass combustion plants]. In: (Hrsg. KJ Thomé-Kozmiensky and M Beckmann) Energie aus Abfall, 2008, Band 5. Neuruppin: TK Verlag Karl Thomé-Kozmiensky.

Spiegel W, Herzog T, Jordan R, et al. (2010) Empirische Befunde am Kessel - Wärmestromdichte korreliert mit korrosionsdynamik [Empirical findings on the boiler]. In: (Hrsg. KJ Thomé-Kozmiensky and M Beckmann) Energie aus Abfall, Band 7. Neuruppin: TK Verlag Karl ThoméKozmiensky.

Tamura M, Weber R and van de Kamp W (2001) Characterisation of alternative fuels for co-firing with pulverized coal. In: Proceedings of the 13th IFRF Members Conference, IFRF, Leeuwenhorst Congress Center, Noordwijerhout, The Netherlands. Tuscany, Italy: IFRF.

Tanner E (1933) Der Temperaturverlauf im Brennstoffbett und im Rost bei der Verbrennung von Steinkohle [The temperature variation in the fuel bed and grate in the combustion of coal]. Dissertation TU Darmstadt.

Thiel S (2007) Mitverbrennung von Ersatzbrennstoffen aus der mechanischbiologischen Abfallbehandlung in Kohlekraftwerken [Co-combustion of refuse derived fuels from mechanical-biological waste treatment in coal power plants]. Dissertation, TK Verlag.

Thiel S (2011) Mitverbrennung von Ersatzbrennstoffen in Kohlekraftwerken [Co-combustion of refuse derived fuels from mechanical-biological waste treatment in coal power plants]. In: (Hrsg. KJ Thomé-Kozmiensky and M Beckmann) Erneuerbare Energien - Band 6. Neuruppin: TK Verlag Karl Thomé-Kozmiensky, pp. S.315-328.

Thiel C, Bernhardt D, Pohl M, et al. (2011) Kreislaufelemente bei einer 50 KW-Braunkohlestaubfeuerung unter Oxy-Fuel Bedingungen [Circulation elements on a $50-\mathrm{kW}$ pulverized lignite combustion under oxy-fuel conditions]. In: (eds M Beckmann and A Hurtado) Kraftwerkstechnik-
Sichere und nachhaltige Energieversorgung, 2011, Band 3. Neuruppin: TK Verlag Karl-Thomé-Kozmiensky, pp. S.117-130.

TUD (ed.) (2011): http://www.kraftwerkstechnik-dresden.de (accessed 15 June 2011).

Unz S, Wen T and Beckmann M (2010) Characterization of biomass used in thermal processes with regard to the kinetic properties. In: Proceedings of the 35th International Technical Conference on Clean Coal \& Fuel Systems, 6-10 June 2010, Clearwater (USA). North Potomac, MD: Coal Technology Association.

Weber R (2005) Characterization of alternative fuels. In: (Hrsg. KJ ThoméKozmiensky and M Beckmann) Optimierung der Abfallverbrennung, 2005, Band 2. Neuruppin: TK Verlag Karl-Thomé-Kozmiensky, pp. S.699-708.

Weber R, Brauckmann D, Scholz R, et al. (2002) Numerical simulations of cement kiln flame. In: Proceedings of the 6th European Conference on Industrial Furnaces and Boilers, Estoril, Lisbon, Portugal, 2-5 April 2002. Lisbon: IINFUB.

Weber T, Gehrmann H-J, Horn J, et al. (2007): Thermische Verwertung von Ersatzbrennstoffen auf einem MARTIN Rückschub-Rost; Untersuchungen zum Abbrandverhalten im Festbettreaktor und Übertragung der Ergebnisse auf den industriellen Prozess [Thermal utilization of alternative fuels]. In: Flammentag Berlin, 12-13 September 2007. Dusseldorf: VPI Verlag.

Weigl S (2009) Modellierung und experimentelle Untersuchungen zum Oxyfuel-Prozess an einer $50 \mathrm{~kW}$ Staubfeuerungs-Versuchsanlage [Modeling and experimental investigations on the oxyfuel process on a $50 \mathrm{~kW}$ pulverized combustion test facility]. Dissertation, Dresden.

Werkmeister H (1932) Versuche über den Verbrennungsverlauf bei Steinkohlen mittlerer Korngrößen [Experiments on the combustion behavior in coal average grain sizes]. Dissertation TH Hannover.

Wilhelm R (2010) Bildung und Reduktion von Stickoxiden bei Braunkohlefeuerungen im Luft- und Oxyfuel-Betrieb [Formation and reduction of nitrogen oxides in lignite fired plants]. Dissertation, ShakerVerlag.

Zelkowski J (2004) Kohleverbrennung - Brennstoff, Physik und Theorie [Coal combustion - fuel, physics and theory]. In: Technik. 2. Auflage, Band 8 der Fachbuchreihe 'Kraftwerkstechnik'.: VGB Technische Vereinigung der Großkraftwerksbetreiber e.V.

Zeuthen JH, Pedersen AJ, Riber C, et al. (2007): Combustion aerosols from municipal waste incineration - effects of feedstock composition and boiler operation. Combustion Science Technologies 179: 2171-2198. 